\title{
The influence of chemical prehistory on the structure, photoluminescent properties, surface and biological characteristics of $\mathrm{Zr}_{0.98} \mathrm{Eu}_{0.02} \mathrm{O}_{1.99}$ nanophosphors
}

\author{
A. N. Bugrov ${ }^{1,2}$, R. Yu. Smyslov ${ }^{1,3}$, A. Yu. Zavialova ${ }^{2,4}$, G. P. Kopitsa ${ }^{5,6}$ \\ ${ }^{1}$ Institute of Macromolecular Compounds of RAS, Bolshoy pr. 31, 199004 St. Petersburg, Russia \\ ${ }^{2}$ St. Petersburg Electrotechnical University "LETI", ul. Professora Popova 5, 197376 St. Petersburg, Russia \\ ${ }^{3}$ Peter the Great St. Petersburg Polytechnic University, Polytechnicheskaya 29, 195251 St. Petersburg, Russia \\ ${ }^{4}$ St. Petersburg State Institute of Technology (Technical University), Moskovsky prospect 26, \\ St. Petersburg, 190013, Russia \\ ${ }^{5}$ St. Petersburg Nuclear Physics Institute, NRC KI, Orlova roscha mcr. 1, \\ Gatchina, Leningrad region, 188300, Russia \\ ${ }^{6}$ Grebenshchikov Institute of Silicate Chemistry RAS, Makarova nab. 2., letter B, 199034 St. Petersburg, Russia \\ alexander.n.bugrov@gmail.com, urs1968@gmail.com,zavialova.a.y@gmail.com, kopitsa_gp@pnpi.nrcki.ru
}

PACS 78.67. $\mathrm{n}$; 78.67.Bf

DOI 10.17586/2220-8054-2019-10-2-164-175

$\mathrm{ZrO}_{2}$ nanoparticles doped with $2 \mathrm{~mol} \%$ of $\mathrm{EuO}_{1.5}$ were obtained from solutions of inorganic salts, zirconium alkoxide and chelating compounds under hydro and solvothermal conditions. The phase compositions of the synthesized nanophosphors were determined using the methods of $\mathrm{X}$-ray diffraction, photoluminescence and Raman spectroscopy. The changes in a particle size, the value of the specific surface area and its charge depending on the conditions of preparation (the type of solvent, isothermal exposure time) and the precursor nature used in the synthesis were considered. It was found that $\mathrm{Zr}_{0.98} \mathrm{Eu}_{0.02} \mathrm{O}_{1.99}$ nanoparticles with a high content of the monoclinic phase, synthesized from zirconium and europium acetylacetonates, have the highest luminescence efficiency. At the same time, the maximum photoluminescence lifetime and the least cytotoxicity were characteristic of crystal phosphors with a more symmetrical crystal lattice of the host matrix, as well as a high surface area/volume ratio.

Keywords: solvothermal synthesis, zirconia, europium, phase transitions, nanoparticles, photoluminescence, fluorescence lifetime, quantum yield, cytotoxicity.

Received: 27 March 2019

Revised: 10 April 2019

\section{Introduction}

The rapid development of solid-state lighting technology has led to an increased demand for high-performance alternative luminescent sources of radiation [1]. It is known that $\mathrm{Ln}^{3+}$-doped wide-bandgap semiconductor oxides can exhibit unique optical properties such as single or multicolor radiation, large Stokes shift, narrow spectral transition bands, long lifetime, and high photoluminescence quantum yield $[2,3]$. The optical properties of oxide nanoparticles doped with $\mathrm{Ln}^{3+}$ largely depend on the type and structure of the host matrix $[4,5]$. Therefore, the correct selection of the absorption oscillator is significant for achieving the desired photoluminescence characteristics of lanthanide ions. Nanocrystalline zirconia is the most suitable host matrix for the creation of high-performance solid-state light-emitting devices based on $\mathrm{Ln}^{3+}$ ions due to its high refractive index, the band gap in the range from 4 to $6 \mathrm{eV}$, transparency in the visible and infrared spectral regions, as well as low frequency of phonons $\left(470 \mathrm{~cm}^{-1}\right)$ [6,7]. To date, nanophosphors based on $\mathrm{ZrO}_{2}$ have been used in LEDs [8], fuel cells [9], solar panels [10], gas sensors [11], and photocatalytic systems $[12,13]$. The photostability and high lifetime of $\mathrm{Ln}^{3+}($ the range of milliseconds) ion radiation in the $\mathrm{ZrO}_{2}$ biologically-inert matrix made it possible to use such luminescent markers for medical purposes for detecting, visualizing, diagnosing and treating diseases [14-17].

For increasing the luminescence efficiency of lanthanide ions, as a rule, uniformity of their distribution in the $\mathrm{ZrO}_{2}$ crystal lattice is required [18]. From this point of view, the methods of "soft chemistry" such as hydro and solvothermal synthesis are preferred [19-21]. They make it possible to control the processes of nucleation and crystallite growth by changing the treatment parameters, which leads to the formation of weakly aggregated particles of a given morphology with a narrow size distribution [22-24]. In turn, the different nature of the precursor and the composition of the reaction medium (e.g. water, an organic solvent, surfactant, mineralizer) predetermine the presence of the required functional groups on the surface of the nanoparticles being synthesized, which can then be used for conjugation with biomolecules [16,25]. 
Selectivity for the excitation wavelength, energy transfer efficiency, lifetime and quantum yield of photoluminescence are determined mainly by the structure and size of $\mathrm{ZrO}_{2}$ crystals, as well as the concentration and localization of $\mathrm{Ln}^{3+}$ active centers in them [26-29]. The distribution of trivalent lanthanide ions between the amorphous, monoclinic and more symmetrical tetragonal and cubic phases of $\mathrm{ZrO}_{2}$ can be adequately distinguished using Eu3+ as a probe. Luminescent properties of europium ions are susceptible to changes in the first coordination sphere, which is manifested in the emission/excitation spectra and the dynamics of the excited state of $\mathrm{ZrO}_{2}: \mathrm{Ln}^{3+}$ nanoparticles [26,30].

In this connection, this work aimed to study the influence of chemical prehistory on the structure of $\mathrm{Zr}_{0.98} \mathrm{Eu}_{0.02} \mathrm{O}_{1.99}$ nanoparticles, formed in the conditions of hydrothermal and solvothermal synthesis, using the europium ions as local probes. In addition, we sought to determine the interrelation of structural and dimensional parameters with the efficiency of luminescence of the obtained crystalline phosphors, as well as the analysis of their cytotoxicity depending on the evolution of surface characteristics concerning dermal fibroblasts to establish the possibility of their further biomedical application.

\section{Experimental methods}

\subsection{Materials}

The following reagents were used in the hydro and solvothermal synthesis of luminescent nanoparticles studied in this work: zirconium (IV) oxychloride octahydrate (98.5\%, Neva-Reactive, Saint Petersburg, Russia, CAS: 7699-43-6); zirconium (IV) acetylacetonate ( $\mathrm{Zr}(\mathrm{acac})_{4} ; 97$ \%, Vecton, Saint Petersburg, Russia, CAS: 17501-44-9); zirconium (IV) n-butoxide solution $\left(\mathrm{Zr}\left(\mathrm{OBu}^{n}\right)_{4} ; 80 \mathrm{wt} . \%\right.$ in 1-butanol, Sigma-Aldrich, St. Louis, MO, USA, CAS: 1071-76-7); europium (III) chloride hexahydrate (99.9 \% trace metals basis, Sigma-Aldrich, St. Louis, MO, USA, CAS: 13759-92-7); europium (III) acetylacetonate hydrate $\left(\mathrm{Eu}(\mathrm{acac})_{3} \times n \mathrm{H}_{2} \mathrm{O} ; 99.9 \%\right.$ trace metals basis, SigmaAldrich, St. Louis, MO, USA, CAS: 62667-64-5); ammonium hydroxide solution (25\%, Neva-Reactive, Saint Petersburg, Russia, CAS: 1336-21-6); ethanol (95\%, Vecton, Saint Petersburg, Russia, CAS: 64-17-5). Toluene (99.5 \%, Vecton, Saint Petersburg, Russia, CAS: 108-88-3) was distilled before use.

\subsection{Hydrothermal synthesis of nanoparticles}

$\mathrm{ZrO}_{2}$ nanoparticles containing $2 \mathrm{~mol} \%$ of $\mathrm{EuO}_{1.5}$ were obtained by co-precipitating zirconium and europium hydroxides from $0.5 \mathrm{M}$ solutions of their chlorides at $\mathrm{pH}=9$, using ammonia water $(25 \%)$. The precipitate was washed with distilled water until a negative reaction to chloride ions by repeated stirring with followed decantation and then dried in air at $100{ }^{\circ} \mathrm{C}$. The obtained $\mathrm{ZrO}(\mathrm{OH})_{2}-\mathrm{Eu}(\mathrm{OH})_{3}$ powder was redispersed in distilled water $(\mathrm{pH}=4-5)$, placed in a steel autoclave and treated under hydrothermal conditions during 4 hours at $250{ }^{\circ} \mathrm{C}$.

\subsection{Solvothermal synthesis of nanoparticles}

The $\mathrm{Eu}(\mathrm{acac})_{3} \times n \mathrm{H}_{2} \mathrm{O}$ with a mass of $0.04 \mathrm{~g}$ was previously dissolved in anhydrous toluene for 3 hours with constant stirring. Zirconium acetylacetonate or butoxide in the amount of $1.87 \mathrm{~g}$ and $1.35 \mathrm{ml}$, respectively, were added to the obtained solutions. The resulting reaction mixtures were then magnetically stirred for 24 hours. The thermal treatment of solutions of organometallic compounds in toluene with $\mathrm{pH}=4-5$ was carried out in steel autoclaves at a temperature of $250{ }^{\circ} \mathrm{C}$ for 72 hours. The obtained powders of $\mathrm{Zr}_{0.98} \mathrm{Eu}_{0.02} \mathrm{O}_{1.99}$ nanoparticles were repeatedly washed in ethanol, followed by centrifugation to remove organic impurities. After that, they were dried at $100{ }^{\circ} \mathrm{C}$ to constant weight and annealed in air at $500{ }^{\circ} \mathrm{C}$ for 2 hours.

\subsection{Characterization techniques}

The elemental composition of the $\mathrm{Zr}_{1-x} \mathrm{Eu}_{x} \mathrm{O}_{2-0.5 x}$ nanopowders obtained in the study was determined using energy-dispersive X-ray spectroscopy (EDX; SUPRA 55VP Carl Zeiss AG with an INCA microanalysis system, Germany) and X-ray fluorescence analysis (XRF; Spectroscan Max-GF2E spectrometer Spectron, Russia Q5). $\mathrm{ZrO}_{2}$ nanoparticles doped with $2 \mathrm{~mol} . \% \mathrm{Eu}^{3+}$ ions were characterized using an X-ray diffraction method (XRD; Rigaku SmartLab diffractometer) with CuK $\alpha$ radiation $(40 \mathrm{kV}$ and $40 \mathrm{~mA})$, scan rate of $0.5^{\circ} / \mathrm{min}$ in a range of $2 \theta$ angles from 10 to $80^{\circ}$. The PD-Win 4.0 [31] and ReX [32] software complexes, as well as ASTM and COD databases, were used to determine the phase composition and calculate the unit cell parameters of the nanoparticles. Transmission electron microscopy (TEM; JEOL JEM-2100F) with an accelerating voltage of $200 \mathrm{kV}$ was used to determine the shape and size of the $\mathrm{Zr}_{0.98} \mathrm{Eu}_{0.02} \mathrm{O}_{1.99}$ nanoparticles. The phase composition of the synthesized nanophosphors was analyzed using Raman spectroscopy (RS; LabRAM HR800, Horiba Jobin-Yvon) at room temperature with $488 \mathrm{~nm}$ of $\mathrm{Ar}^{+}$laser. A specific surface area (SBET) and porosity of synthesized nanopowders were determined by low-temperature nitrogen adsorption (QuantaChrome Nova 4200B analyzer, 
Quantachrome Instruments, USA). Zeta potential was determined using an electrophoretic light scattering method (Malvern Zetasizer Nano ZS laser analyzer, Malvern Instruments, UK) at $25^{\circ} \mathrm{C}$, pH value of 6.4 with a background electrolyte concentration $(\mathrm{NaCl})$ of $10^{-3} \mathrm{M}$. The optical band gap of nanocrystals based on zirconia was determined using diffuse reflectance spectra (Shimadzu UV-2550 spectrophotometer equipped with an ISR-2200 integrating sphere). MTT assay of $\mathrm{ZrO}_{2}-2$ mol.\% EuO $\mathrm{Eu}_{1.5}$ nanoparticles were carried out on dermal fibroblasts in accordance with the procedure described in detail in [33]. The photoluminescence (PL) quantum yield of nanophosphors was measured by the modified de Mello's method using a Fluorolog-3 fluorescence spectrometer equipped with a Quanta-j integrating sphere [34]. The excitation and emission spectra of nanoparticle powders were studied using a luminescence spectrophotometer LS-100 (PTI $尺$, Canada). The luminescence lifetimes of $\mathrm{Zr}_{0.98} \mathrm{Eu}_{0.02} \mathrm{O}_{1.99}$ nanoparticles were determined from the emission intensity decay using a pulse xenon lamp.

\section{Results and discussion}

The effects of the chemical prehistory of $\mathrm{ZrO}_{2}-2$ mol.\% EuO $\mathrm{Eu}_{1.5}$ nanoparticles on their phase composition, specific surface area, porosity, electrokinetic potential, photoluminescence, and biological activity were considered.

The elemental analysis of $\mathrm{Zr}_{1-x} \mathrm{Eu}_{x} \mathrm{O}_{2-0.5 x}$ nanoparticle samples is carried out under the conditions of hydro and solvothermal treatment corresponded to the 98 mol.\% $\mathrm{ZrO}_{2} / 2 \mathrm{~mol} \% \mathrm{EuO}_{1.5}$ ratio, according to the EDX and XRF methods (Table 1). The data obtained coincide within the error with the composition preset by the synthesis.

TABLE 1. Elemental analysis of synthesized nanoparticles based on $\mathrm{ZrO}_{2}$ doped with $\mathrm{EuO}_{1.5}$

\begin{tabular}{|c|c|c|c|c|}
\hline \multirow[t]{2}{*}{ Chemical prehistory } & \multicolumn{2}{|c|}{$\begin{array}{l}\text { Data of fluorescence analysis } \\
\text { calculated as oxides, mol.\% }\end{array}$} & \multicolumn{2}{|c|}{$\begin{array}{c}\text { Data of EDX-analysis } \\
\text { calculated as oxides, mol.\% }\end{array}$} \\
\hline & $\mathrm{ZrO}_{2}$ & $\mathrm{EuO}_{1.5}$ & $\mathrm{ZrO}_{2}$ & $\mathrm{EuO}_{1.5}$ \\
\hline $\mathrm{ZrOCl}_{2} \times 8 \mathrm{H}_{2} \mathrm{O} / \mathrm{EuCl}_{3} \times 6 \mathrm{H}_{2} \mathrm{O}$ & $97.8 \pm 2.9$ & $2.2 \pm 0.1$ & $97.1 \pm 4.9$ & $2.9 \pm 0.2$ \\
\hline $\mathrm{Zr}(\mathrm{acac})_{4} / \mathrm{Eu}(\mathrm{acac})_{3} \times n \mathrm{H}_{2} \mathrm{O}$ & $98.2 \pm 3.0$ & $1.8 \pm 0.1$ & $98.1 \pm 4.9$ & $1.9 \pm 0.1$ \\
\hline $\mathrm{Zr}\left(\mathrm{OBu}^{n}\right)_{4} / \mathrm{Eu}(\mathrm{acac})_{3} \times n \mathrm{H}_{2} \mathrm{O}$ & $98.1 \pm 2.9$ & $1.9 \pm 0.1$ & $97.7 \pm 4.9$ & $2.3 \pm 0.1$ \\
\hline
\end{tabular}

The PD-Win 4.0 and ReX software complexes, along with ASTM and COD databases [35-37] were used to determine the phase composition, calculate the average size of coherent scattering regions, as well as the lattice parameters for the unit cell of $\mathrm{Zr}_{0.98} \mathrm{Eu}_{0.02} \mathrm{O}_{1.99}$ nanoparticles. Nanophosphors obtained from $0.5 \mathrm{M}$ solutions of $\mathrm{ZrOCl}_{2} \times 8 \mathrm{H}_{2} \mathrm{O}$ and $\mathrm{EuCl}_{3} \times 6 \mathrm{H}_{2} \mathrm{O}$ by coprecipitating with following hydrothermal treatment are a mixture of tetragonal $(t)$, cubic $(c)$ and monoclinic $(m)$ zirconia phases in the 74.8/12.2/13 ratio (Fig. 1, pattern 1 ). The phase composition of nanoparticles synthesized by the treatment of toluene solutions of $\mathrm{Zr}(\mathrm{acac})_{4}$ and Eu(acac $)_{3} \times n \mathrm{H}_{2} \mathrm{O}$ at an elevated temperature and pressure includes 46.9 vol.\% tetragonal, 23.5 vol. \% cubic and 29.6 vol.\% monoclinic zirconia (Fig. 1, pattern 2), according to results of XRD pattern analysis. A monoclinic phase is not observed in the sample, but $t$ - and $c-\mathrm{ZrO}_{2}$ are present in the ratio 33.8/66.2 if $\mathrm{Zr}\left(\mathrm{OBu}^{n}\right)_{4}$ is used as a precursor (Fig. 1, pattern 3, and Table 2). The parameters and the volume of the unit cell in the $\mathrm{Cl}^{-} \rightarrow \mathrm{C}_{5} \mathrm{H}_{7} \mathrm{O}_{2}^{-} \rightarrow \mathrm{C}_{4} \mathrm{H}_{9} \mathrm{O}^{-}$ series decrease for $t-\mathrm{ZrO}_{2}$, and grow for its cubic phase. For nanopowders obtained from precursors of different nature, the average sizes of coherent scattering regions calculated by the Debye-Scherrer formula are comparable with the particle diameter fixed by the TEM (Table 2, Fig. 2). According to microphotographs, the average diameter of $\mathrm{Zr}_{0.98} \mathrm{Eu}_{0.02} \mathrm{O}_{1.99}$ quasi-spherical particles obtained by the solvothermal synthesis from zirconium and europium acetylacetonates was $8 \mathrm{~nm}$, and in the case of a mixture of $\mathrm{Zr}\left(\mathrm{OBu}^{n}\right)_{4} / \mathrm{Eu}(\mathrm{acac})_{3} \times n \mathrm{H}_{2} \mathrm{O}-4 \mathrm{~nm}$ (Fig. 2, micrograph 2 and 3). The dehydration under hydrothermal conditions of $\mathrm{ZrO}(\mathrm{OH})_{2}-\mathrm{Eu}(\mathrm{OH})_{3}$ mixture co-precipitated from inorganic salts leads to the crystallization of nanophosphors larger size of about $15 \mathrm{~nm}$ (Fig. 2 , micrograph 1).

In the Raman spectra of the nanoparticles obtained from precursors of different nature, there are apparent differences in the phase composition (Fig. 3). The use of zirconium and europium acetylacetonates as the starting materials in the synthesis of $\mathrm{ZrO}_{2}-2$ mol.\% $\mathrm{EuO}_{1.5}$ nanoparticles leads to a significant increase in the content of the monoclonal phase (peaks at $183,335,533,556,613 \mathrm{~cm}^{-1}$ ) and a decrease in the volume fraction of the 


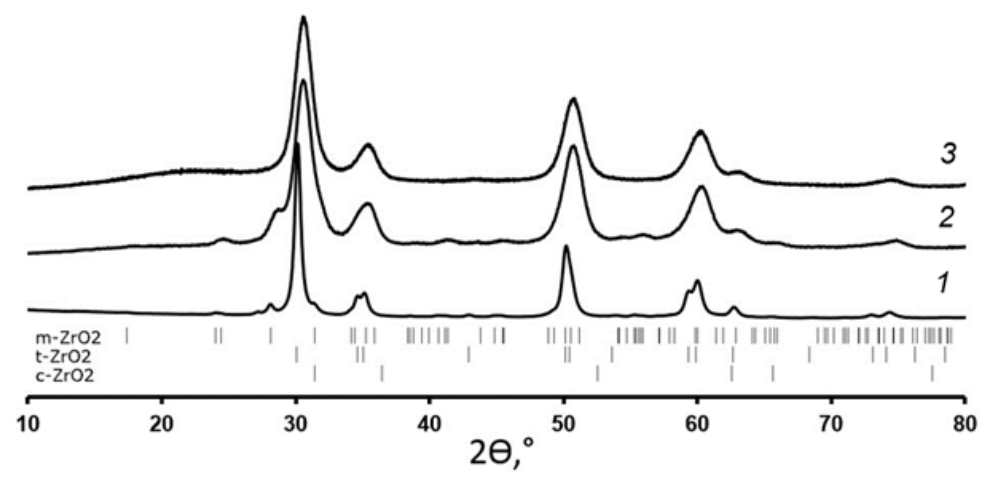

FIG. 1. X-ray diffraction patterns of $\mathrm{Zr}_{0.98} \mathrm{Eu}_{0.02} \mathrm{O}_{1.99}$ nanoparticles synthesized from $\mathrm{ZrOCl}_{2}$ and $\mathrm{EuCl}_{3}$ crystalline hydrates (1), $\mathrm{Zr}(\text { acac })_{4}$ and $\mathrm{Eu}(\mathrm{acac})_{3} \times n \mathrm{H}_{2} \mathrm{O}$ (2), as well as $\mathrm{Zr}\left(\mathrm{OBu}^{n}\right)_{4}$ and $\mathrm{Eu}(\mathrm{acac})_{3} \times n \mathrm{H}_{2} \mathrm{O}$ (3)

TABLE 2. Structural parameters of $\mathrm{Zr}_{0.98} \mathrm{Eu}_{0.02} \mathrm{O}_{1.99}$ nanoparticles synthesized in hydro- and solvothermal conditions from inorganic salts, metal alkoxide and chelating agents

\begin{tabular}{|c|c|c|c|}
\hline $\begin{array}{l}\text { Chemical } \\
\text { prehistory }\end{array}$ & $\begin{array}{c}\text { Phase } \\
\text { composition }\end{array}$ & Unit cell parameters & $\begin{array}{l}\text { Average crystallite } \\
\text { size (XRD), nm }\end{array}$ \\
\hline \multirow{3}{*}{$\begin{aligned} \mathrm{ZrOCl}_{2} & \times 8 \mathrm{H}_{2} \mathrm{O} / \\
\mathrm{EuCl}_{3} & \times 6 \mathrm{H}_{2} \mathrm{O}\end{aligned}$} & 13 vol. $\% m-\mathrm{ZrO}_{2}$ & $\begin{array}{c}a=5.1783 ; b=5.2099 ; c=5.3171 ; \\
\alpha=\gamma=90^{\circ} ; \beta=99.25^{\circ} ; V=141.6 \AA^{3}\end{array}$ & $15 \pm 3$ \\
\hline & 74.8 vol. $\% t-\mathrm{ZrO}_{2}$ & $\begin{array}{c}a=b=3.6032 ; c=5.1827 \\
\alpha=\beta=\gamma=90^{\circ} ; V=67.3 \AA^{3}\end{array}$ & $15 \pm 3$ \\
\hline & 12.2 vol. $\% c-\mathrm{ZrO}_{2}$ & $\begin{array}{c}a=b=c=5.1272 \\
\alpha=\beta=\gamma=90^{\circ} ; V=134.8 \AA^{3}\end{array}$ & $15 \pm 3$ \\
\hline \multirow{3}{*}{$\begin{array}{c}\mathrm{Zr}(\mathrm{acac})_{4} / \\
\mathrm{Eu}(\mathrm{acac})_{3} \times n \mathrm{H}_{2} \mathrm{O}\end{array}$} & 23.5 vol. $\% m-\mathrm{ZrO}_{2}$ & $\begin{array}{c}a=5.1578 ; b=5.1975 ; c=5.3194 \\
\alpha=\gamma=90^{\circ} ; \beta=99.14^{\circ} ; V=140.8 \AA^{3}\end{array}$ & $8 \pm 2$ \\
\hline & 46.9 vol. $\% t-\mathrm{ZrO}_{2}$ & $\begin{array}{c}a=b=3.5964 ; c=5.1872 \\
\alpha=\beta=\gamma=90^{\circ} ; V=67.1 \AA^{3}\end{array}$ & $6 \pm 2$ \\
\hline & 29.6 vol. $\% c-\mathrm{ZrO}_{2}$ & $\begin{array}{c}a=b=c=5.1313 \\
\alpha=\beta=\gamma=90^{\circ} ; V=135.1 \AA^{3}\end{array}$ & $6 \pm 2$ \\
\hline \multirow{2}{*}{$\begin{array}{c}\mathrm{Zr}\left(\mathrm{OBu}^{n}\right)_{4} / \\
\mathrm{Eu}(\mathrm{acac})_{3} \times n \mathrm{H}_{2} \mathrm{O}\end{array}$} & 33.8 vol. $\% t-\mathrm{ZrO}_{2}$ & $\begin{array}{c}a=b=3.5885 ; c=5.1552 \\
\alpha=\beta=\gamma=90^{\circ} ; V=66.4 \AA^{3}\end{array}$ & $4 \pm 1$ \\
\hline & 66.2 vol. $\% c-\mathrm{ZrO}_{2}$ & $\begin{array}{c}a=b=c=5.1567 \\
\alpha=\beta=\gamma=90^{\circ} ; V=137.1 \AA^{3}\end{array}$ & $4 \pm 1$ \\
\hline
\end{tabular}

tetragonal polymorphic modification (peaks at 149, 224, 292, 324, 407, 456 and $636 \mathrm{~cm}^{-1}$ ) in comparison with analogs obtained from solutions of chlorides. Solvothermal treatment of $\mathrm{Zr}\left(\mathrm{OBu}^{n}\right)_{4} / \mathrm{Eu}(\mathrm{acac})_{3} \times n \mathrm{H}_{2} \mathrm{O}$ mixture in toluene makes it possible to synthesize nanoparticles mainly with the $c-\mathrm{ZrO}_{2}$ structure characterized by a wide band of $530-670 \mathrm{~cm}^{-1}$ in the Raman spectra, as well as a unique phonon band $\mathrm{F} 2 \mathrm{~g}$ of ca. $625 \mathrm{~cm}^{-1}$ [7]. RS data confirm the phase composition determined by XRD (Table 2).

Based on the diffuse reflectance spectra $R(\lambda)$ in the visible and ultraviolet range from 2.5 to $6 \mathrm{eV}$, one calculated the Schuster-Kubelka-Munk or remission function [38]:

$$
F\left(R_{\infty}(\lambda)\right)=\frac{\left(1-R_{\infty}(\lambda)\right)^{2}}{2 R_{\infty}(\lambda)}=\frac{K}{S}=\frac{2.303 \varepsilon C}{S},
$$

where $R_{\infty}(\lambda)$ is the value of reflectance when it is already not changed in increasing system thickness; $K$ is the absorption coefficient (twice the Beer's law absorption coefficient); $S$ is twice the scattering coefficient of the sample; $\varepsilon$ is the absorptivity, and $C$ is the analyte concentration.

Using the plot of $\left(F\left(R_{\infty}\right) h \nu\right)^{1 / \eta}$ versus energy, $h \nu$, one can estimate the optical bandgap, $E_{g}$, between the conduction band and the valence one in $\mathrm{Zr}_{0.98} \mathrm{Eu}_{0.02} \mathrm{O}_{1.99}$ nanoparticles (Fig. 4). In the region of the highest 


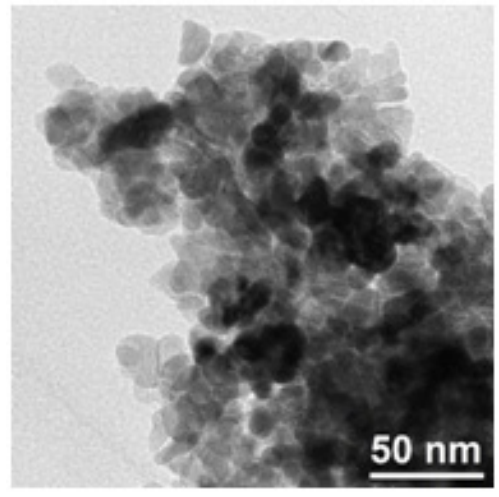

(1)

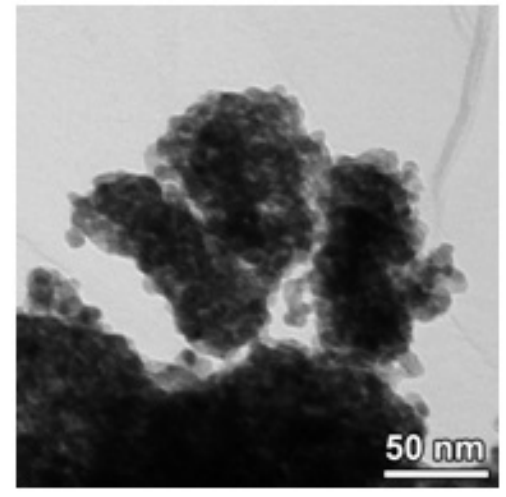

(2)

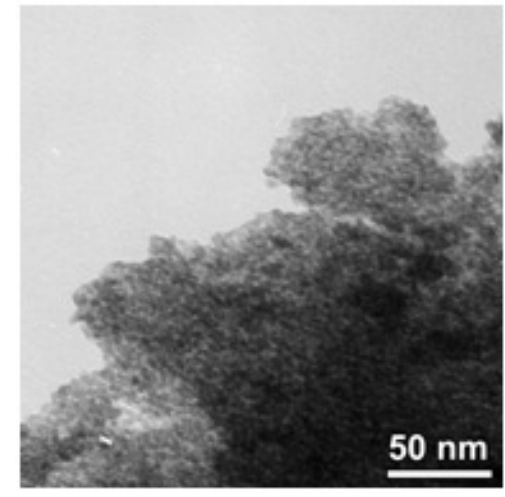

(3)

FIG. 2. TEM micrographs of $\mathrm{Zr}_{0.98} \mathrm{Eu}_{0.02} \mathrm{O}_{1.99}$ nanoparticles synthesized from $\mathrm{ZrOCl}_{2}$ and $\mathrm{EuCl}_{3}$ crystalline hydrates (1), $\mathrm{Zr}(\mathrm{acac})_{4}$ and $\mathrm{Eu}(\mathrm{acac})_{3} \times n \mathrm{H}_{2} \mathrm{O}$ (2), as well as $\mathrm{Zr}\left(\mathrm{OBu}^{n}\right)_{4}$ and $\mathrm{Eu}(\mathrm{acac})_{3} \times n \mathrm{H}_{2} \mathrm{O}(3)$

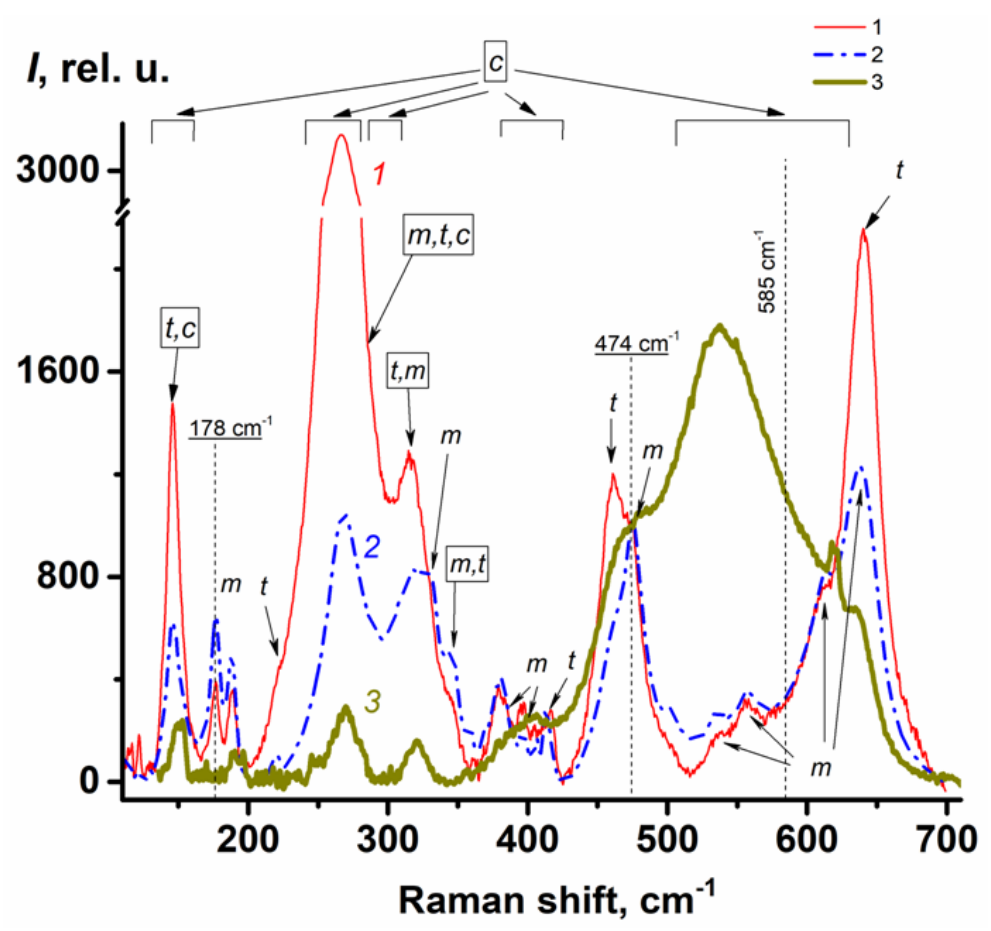

FIG. 3. Raman spectra of $\mathrm{Zr}_{0.98} \mathrm{Eu}_{0.02} \mathrm{O}_{1.99}$ nanoparticles synthesized from $\mathrm{ZrOCl}_{2} \times 8 \mathrm{H}_{2} \mathrm{O}$ and $\mathrm{EuCl}_{3} \times 6 \mathrm{H}_{2} \mathrm{O}(1), \mathrm{Zr}(\mathrm{acac})_{4}$ and $\mathrm{Eu}(\mathrm{acac})_{3} \times n \mathrm{H}_{2} \mathrm{O}(2)$, as well as $\mathrm{Zr}\left(\mathrm{OBu}^{n}\right)_{4}$ and $\mathrm{Eu}(\mathrm{acac})_{3} \times$ $n \mathrm{H}_{2} \mathrm{O}$ (3). Spectra were normalized at $474 \mathrm{~cm}^{-1}$

obtained energy of $5-6 \mathrm{eV}$, the allowed indirect absorption transitions turned out to manifest themselves because there are linear approximations at $\eta=2$ for all the cases under investigation [39]. At that, the $E_{g}$ values of the studied nanoparticles are limited from 4 to $6 \mathrm{eV}$, which is consistent with prior research [6]. The bandgap of $\mathrm{ZrO}_{2}-2$ mol.\% $\mathrm{EuO}_{1.5}$ nanoparticles synthesized from inorganic salts $\left(E_{g 1}\right)$ in comparison with $E_{g 1^{\prime}}$ of undoped zirconia increases from 4.85 to $5.12 \mathrm{eV}$. The introduction of 2 mol.\% of $\mathrm{EuO}_{1.5}$ into zirconia crystal lattice leads to decreasing the value of $\left(F\left(R_{\infty}\right) h \nu\right)^{1 / 2}$ as opposed to it (Note curves 1 and 1 '). This result can mean the higher absorption ability of $m-\mathrm{ZrO}_{2}$, which lessens in doping zirconia by $\mathrm{Eu}^{3+}$, relative to one of $t / c$-phases in the region of $4-5.3 \mathrm{eV}$. For nanoparticles obtained from $\mathrm{Zr}\left(\mathrm{OBu}^{n}\right)_{4}$ and $\mathrm{Zr}(\mathrm{acac})_{4}$, one observed the shifts from $4.85 \mathrm{eV}$ of $E_{g 1^{\prime}}$ to 4.72 and $4.6 \mathrm{eV}$, respectively (Fig. 4). It was found that in the region of $3-4 \mathrm{eV}$ absorption is less 
for $\mathrm{Zr}_{0.98} \mathrm{Eu}_{0.02} \mathrm{O}_{1.99}$ nanoparticles formed from $\mathrm{Zr}\left(\mathrm{OBu}^{n}\right)_{4}$ and $\mathrm{Zr}(\mathrm{acac})_{4}$ as compared to those obtained from $\mathrm{ZrOCl}_{2} \times 8 \mathrm{H}_{2} \mathrm{O}$. Here, the influence of $t$-phase is already reflected; the absorption ability of nanoparticles could decrease with the lower content of it. Moreover, the $c$-phase happens to be the least light-absorbing (Note curve 3, Fig. 4). It should be noted that the smaller additional $E_{g}$ values for the systems synthesized from $\mathrm{ZrOCl}_{2} \times 8 \mathrm{H}_{2} \mathrm{O}$ with 74.8 vol.\% of $t-\mathrm{ZrO}_{2}$, from $\mathrm{Zr}$ (acac $)_{4}$ with 23.5 vol.\% of $m-\mathrm{ZrO}_{2}$, and from $\mathrm{Zr}\left(\mathrm{OBu}^{n}\right)_{4}$ with 66.2 vol.\% of $c-\mathrm{ZrO}_{2}$ are determined from the plot in Fig. 4, as well. They are equal to 4.5, 3.6, and $3.5 \mathrm{eV}$, respectively. These data are consistent with the theoretical minimum $E_{g}$ values obtained by the DFT method for the three different $\mathrm{ZrO}_{2}$ modifications: $4.0 \mathrm{eV}$ for $t-\mathrm{ZrO}_{2}, 3.6 \mathrm{eV}$ for $m-\mathrm{ZrO}_{2}$, and $3.3 \mathrm{eV}$ for $c-\mathrm{ZrO}_{2}$ [40]. Moreover, the shoulder in the range of $3.5-3.9 \mathrm{eV}$ (curve 1, Fig. 4) may be attributed to intersitial oxygen states or oxygen vacancy states [40].

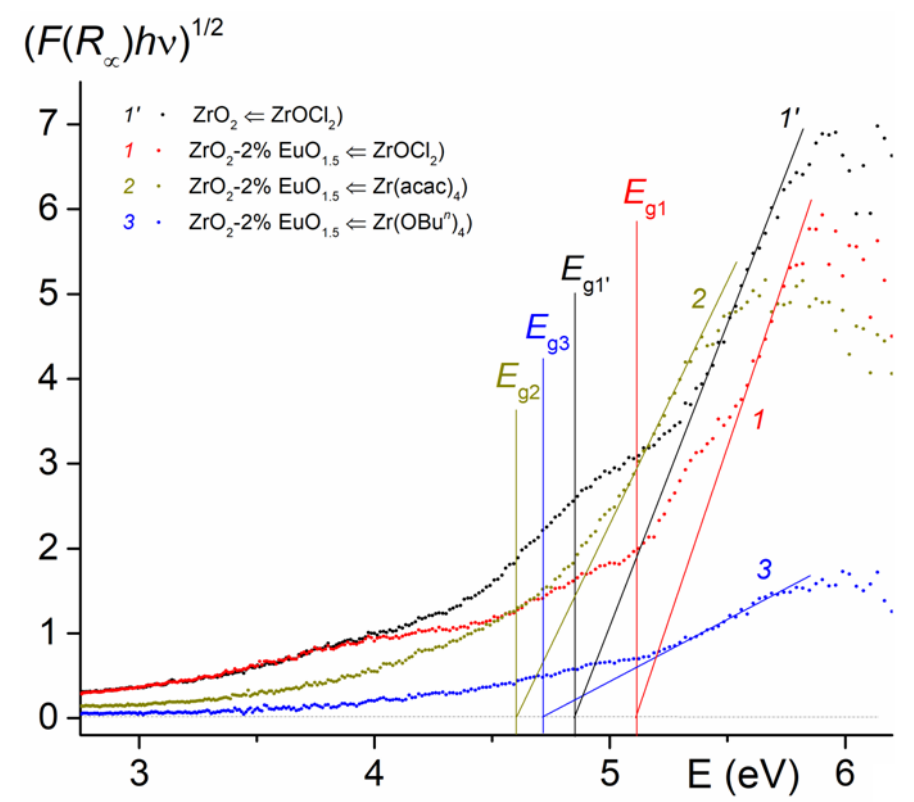

FIG. 4. Absorption spectra of $\mathrm{Zr}_{0.98} \mathrm{Eu}_{0.02} \mathrm{O}_{1.99}$ phosphors synthesized from $\mathrm{ZrOCl}_{2}$ and $\mathrm{EuCl}_{3}$ crystalline hydrates (1), $\mathrm{Zr}(\mathrm{acac})_{4}$ and $\mathrm{Eu}(\mathrm{acac})_{3} \times n \mathrm{H}_{2} \mathrm{O}(2), \mathrm{Zr}\left(\mathrm{OBu}^{n}\right)_{4}$ and $\mathrm{Eu}(\mathrm{acac})_{3} \times$ $n \mathrm{H}_{2} \mathrm{O}$ (3), as well as pure $\mathrm{ZrO}_{2}$ nanoparticles prepared from $\mathrm{ZrOCl}_{2} \times 8 \mathrm{H}_{2} \mathrm{O}$ (1')

The influence of the precursor nature on the photoluminescence of $\mathrm{ZrO}_{2}-2$ mol.\% $\mathrm{EuO}_{1.5}$ nanoparticles synthesized by hydro- and solvothermal synthesis was also studied (Fig. 5). Peaks observed at 591, 607, 614, $628,634,653,659,702$ and $749 \mathrm{~nm}$, as well as the shoulder at $580 \mathrm{~nm}$ can be compared with the spectral terms of the Stark splitting for $\mathrm{Eu}^{3+}$ and the radiative transitions in the Dieke diagram for the $4 f^{n}$ configuration of $\mathrm{Eu}^{3+7} F_{J} \leftarrow{ }^{5} D_{0}(J=0-5)[41,42]$. The excitation spectra (Fig. 6) for these nanoparticles cover the range of intraconfiguration $4 f^{n}-4 f^{n}$ transitions in the region of $270-490 \mathrm{~nm}$. In addition, the peaks at 227, 240, 256, and $265 \mathrm{~nm}$ are correlated with the interconfiguration $4 f^{n}-5 d^{n}$ transitions and charge transfer states. According to the excitation spectra, ones used the PL excitation wavelength of 255, 270, and $397 \mathrm{~nm}$.

At the excitation of $247-255 \mathrm{~nm}$ in PL spectra (Fig. 5a) one observed a weak shoulder or a small peak at $614 \mathrm{~nm}$. At this wavelength, the $m-\mathrm{ZrO}_{2}$ polymorph manifests itself in photoluminescence. Thus, the contribution of the $m-\mathrm{ZrO}_{2}$ increases in the series of $\mathrm{Zr}\left(\mathrm{OBu}^{n}\right)_{4} / \mathrm{Eu}(\mathrm{acac})_{3} \times n \mathrm{H}_{2} \mathrm{O}(3) \rightarrow \mathrm{ZrOCl}_{2} \times 8 \mathrm{H}_{2} \mathrm{O} / \mathrm{EuCl}_{3} \times 6 \mathrm{H}_{2} \mathrm{O}(1) \rightarrow$ $\mathrm{Zr}(\mathrm{acac})_{4} / \mathrm{Eu}(\mathrm{acac})_{3} \times n \mathrm{H}_{2} \mathrm{O}(2)$. The latter fact is reflected in the XRD and RS data (Table 2, Fig. 3) as the growth of the monoclinic phase. To that end, the ratio between the magnetic dipole transfer contribution and the electric dipole transfer one decreases, which indicates the lessening of crystal field symmetry around $\mathrm{Eu}^{3+}$. It means that the pseudocubic $(c / t)$ phase is lowered in the series. Also, it was found out that upon excitation at 270 and $397 \mathrm{~nm}$ of the $4 f^{n}-4 f^{n}$ transitions (Fig. 5b and c), the contribution of the $c-\mathrm{ZrO}_{2}$ in the PL spectra (bands at 606 and $633 \mathrm{~nm})$ of $\mathrm{ZrO}_{2}-2$ mol.\% $\mathrm{EuO}_{1.5}$ nanoparticles increases in the series $\mathrm{ZrOCl}_{2} \times 8 \mathrm{H}_{2} \mathrm{O} / \mathrm{EuCl}_{3} \times 6 \mathrm{H}_{2} \mathrm{O}(1) \rightarrow$ $\mathrm{Zr}(\mathrm{acac})_{4} / \mathrm{Eu}\left(\mathrm{acac}_{2}\right)_{3} \times n \mathrm{H}_{2} \mathrm{O}$ (2) $\rightarrow \mathrm{Zr}\left(\mathrm{OBu}^{n}\right)_{4} / \mathrm{Eu}(\mathrm{acac})_{3} \times n \mathrm{H}_{2} \mathrm{O}$ (3), again consistent with the XRD data (Table 2, Fig. 3). Thus, there is the PL sensitivity of different $\mathrm{ZrO}_{2}$-polymorph modifications to the excitation wavelengths [26]; in a short-wavelength region, the $m-\mathrm{ZrO}_{2}$ determines luminescence, while in the long-wavelength region, the cubic phase is decisive. 

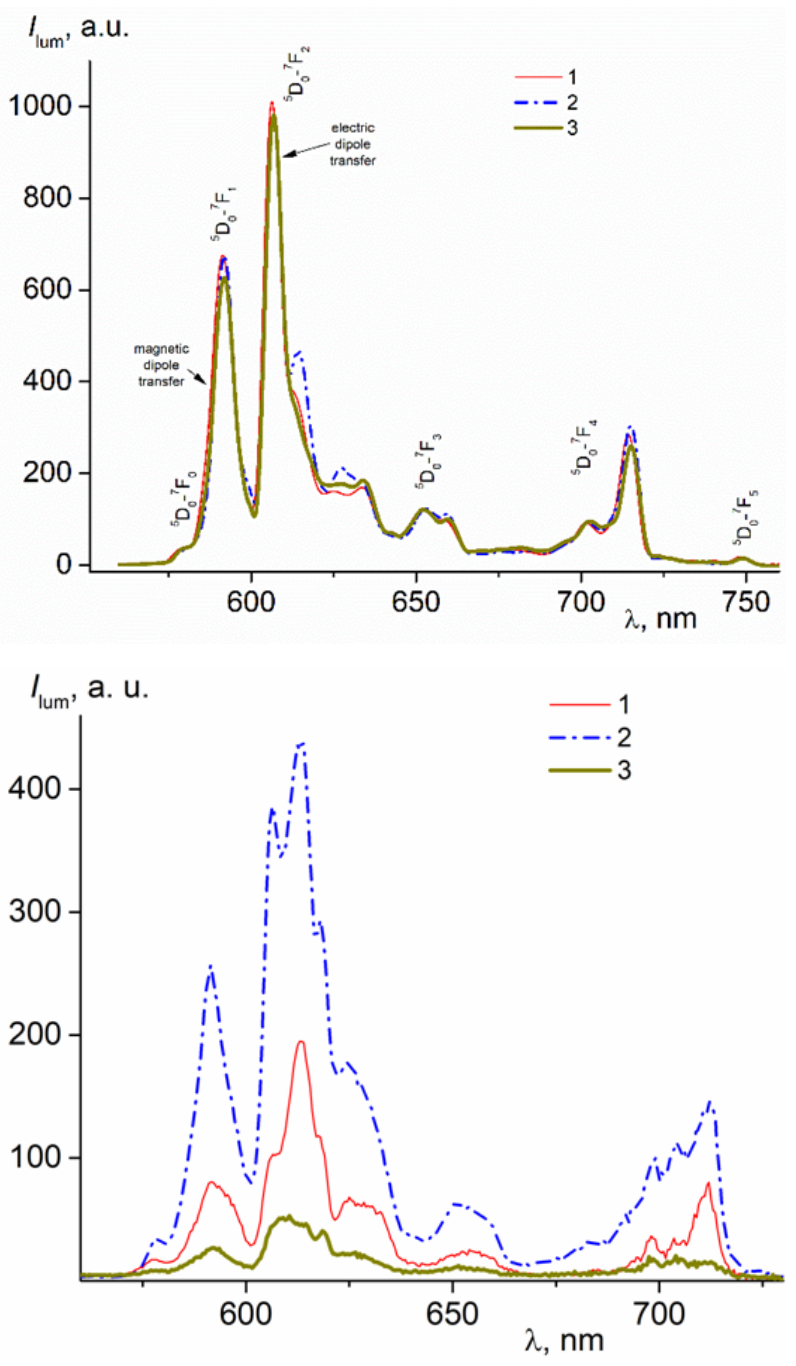

(b)

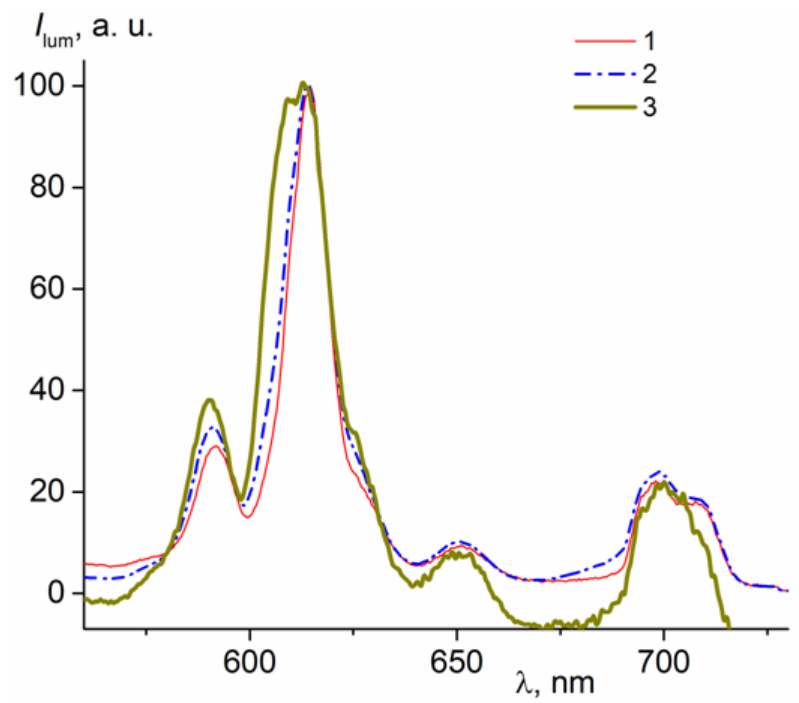

(c)

FIG. 5. The luminescence spectra $(\mathrm{a}-\mathrm{c}$ ), normalized at 606 (a) and $614 \mathrm{~nm}$ (c), for $\mathrm{Zr}_{0.98} \mathrm{Eu}_{0.02} \mathrm{O}_{1.99}$ nanoparticles obtained by hydro and solvothermal synthesis from different precursors: $\mathrm{ZrOCl}_{2}$ and $\mathrm{EuCl}_{3}$ crystalline hydrates (1), $\mathrm{Zr}(\mathrm{acac})_{4}$ and $\mathrm{Eu}(\mathrm{acac})_{3} \times n \mathrm{H}_{2} \mathrm{O}$ (2), $\mathrm{Zr}\left(\mathrm{OBu}^{n}\right)_{4}$ and $\mathrm{Eu}(\mathrm{acac})_{3} \times n \mathrm{H}_{2} \mathrm{O}$ (3). Excitation at $247-255$ (a), 270 (b) and $397 \mathrm{~nm}$ (c) 
The influence of chemical prehistory on the structure, photoluminescent properties, surface...

TABLE 3. Photoluminescence lifetimes ${ }^{1)}$ of $\mathrm{Zr}_{0.98} \mathrm{Eu}_{0.02} \mathrm{O}_{1.99}$ nanoparticles formed from different precursors

\begin{tabular}{|c|c|c|c|c|c|}
\hline Chemical prehistory & $A_{1}$ & $\tau_{\mathrm{PL} 1}, \mathrm{~ms}$ & $A_{2}=1-A_{1}$ & $\tau_{\mathrm{PL} 2}, \mathrm{~ms}$ & $\chi_{\text {red }}^{2}$ \\
\hline \hline $\mathrm{ZrOCl}_{2} \times 8 \mathrm{H}_{2} \mathrm{O} / \mathrm{EuCl}_{3} \times 6 \mathrm{H}_{2} \mathrm{O}$ & 0.687 & 0.865 & 0.313 & 2.21 & 0.751 \\
\hline $\mathrm{Zr}(\mathrm{acac})_{4} / \mathrm{Eu}(\mathrm{acac})_{3} \times n \mathrm{H}_{2} \mathrm{O}$ & 0.628 & 0.768 & 0.372 & 2.02 & 1.518 \\
\hline $\mathrm{Zr}(\mathrm{OBu})_{4} / \mathrm{Eu}(\mathrm{acac})_{3} \times n \mathrm{H}_{2} \mathrm{O}$ & 0.436 & 1.160 & 0.564 & 3.22 & 2.668 \\
\hline
\end{tabular}

${ }^{1)}$ PL lifetimes were fitted on the basis of the dual exponent decay (see Eq. 2) in minimizing a reduced $\chi_{\text {red }}^{2}$ statistics.

${ }^{2)}$ Note the mean-weighted PL lifetimes, $\tau_{\mathrm{PLw}}$, calculated upon Eq. 3 and shown in Fig. 7. function:

The decay of PL intensity $\left(I_{\text {lum }}(t)\right)$ for nanoparticles can be approximated by a model of the dual exponential

$$
I_{\text {lum }}(t)=A_{1} \exp \left(-t / \tau_{\mathrm{PL} 1}\right)+A_{2} \exp \left(-t / \tau_{\mathrm{PL} 2}\right)+B
$$

where $\tau_{\mathrm{PL} 1}$ and $\tau_{\mathrm{PL} 2}$ are the PL lifetime for the first and second emission processes; $A_{1}$ and $A_{2}$ are the first and second pre-exponential factors. Term $B$ is a background contribution. Based on the obtained $\tau_{\mathrm{PL}}$ and their contributions in the two-exponential approximation (Table 3), the weighted-average luminescence lifetimes, $\tau_{\mathrm{PLw}}$, are calculated according to the expression (Fig. 6):

$$
\tau_{P L w}=\frac{\sum_{i=1}^{2} A_{i} \tau_{\mathrm{PL} i}^{2}}{\sum_{i=1}^{2} A_{i} \tau_{\mathrm{PL} i}}
$$

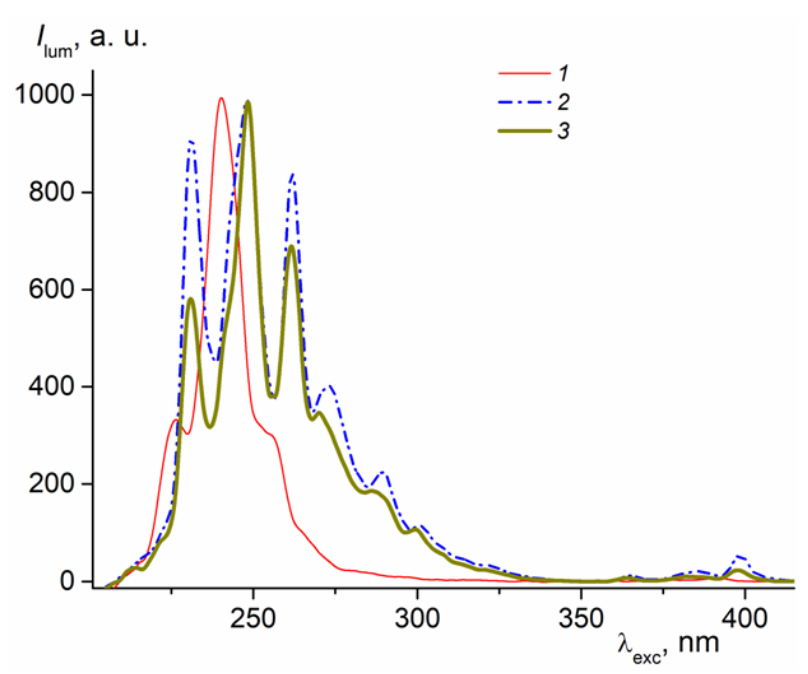

FIG. 6. The normalized excitation spectra of the luminescence of $\mathrm{Zr}_{0.98} \mathrm{Eu}_{0.02} \mathrm{O}_{1.99}$ nanoparticles, obtained by hydro and solvothermal synthesis from different precursors: $\mathrm{ZrOCl}_{2}$ and $\mathrm{EuCl}_{3}$ crystalline hydrates (1), $\mathrm{Zr}(\mathrm{acac})_{4}$ and $\mathrm{Eu}(\mathrm{acac})_{3} \times n \mathrm{H}_{2} \mathrm{O}(2), \mathrm{Zr}\left(\mathrm{OBu}^{n}\right)_{4}$ and $\mathrm{Eu}(\mathrm{acac})_{3} \times n \mathrm{H}_{2} \mathrm{O}$ (3). Luminescence was observed at $606 \mathrm{~nm}(1)$ and $613 \mathrm{~nm}(2,3)$. The spectra are normalized at $240 \mathrm{~nm}(1)$ and $248 \mathrm{~nm}(2,3)$

According to the data shown in Fig. 7, PL lifetimes decrease from 2.8 to $1.5 \mathrm{~ms}$ upon increasing the $m$ $\mathrm{ZrO}_{2}$ content. As a result, the quantum yield rises to $2.3 \%$, as it was fixed in [43].

The results of low-temperature nitrogen adsorption show that $\mathrm{ZrO}_{2}-2$ mol.\% EuO $\mathrm{Eu}_{1.5}$ nanoparticles synthesized from $\mathrm{ZrOCl}_{2} \times 8 \mathrm{H}_{2} \mathrm{O} / \mathrm{EuCl}_{3} \times 6 \mathrm{H}_{2} \mathrm{O}, \mathrm{Zr}(\mathrm{acac})_{4} / \mathrm{Eu}(\mathrm{acac})_{3} \times n \mathrm{H}_{2} \mathrm{O}$ and $\mathrm{Zr}\left(\mathrm{OBu}^{n}\right)_{4} / \mathrm{Eu}(\mathrm{acac})_{3} \times n \mathrm{H}_{2} \mathrm{O}$ are characterized by SBET values of $80.2,91.6$ and $96.6 \mathrm{~m}^{2} / \mathrm{g}$, respectively (Table 4). Sorption isotherms for these nanoparticles 


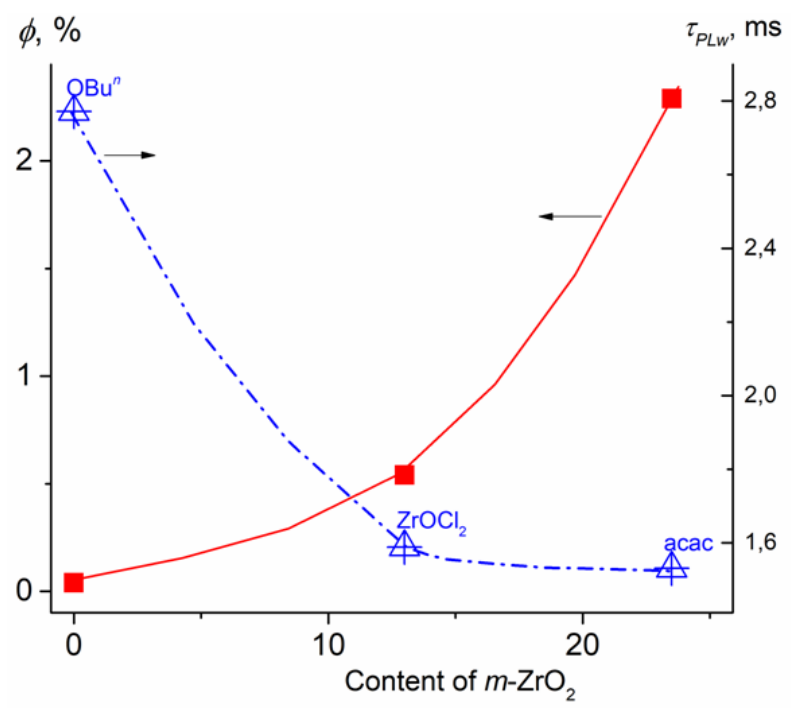

FIG. 7. Dependence of the lifetime and photoluminescence quantum yields of $\mathrm{Zr}_{0.98} \mathrm{Eu}_{0.02} \mathrm{O}_{1.99}$ nanoparticles on the chemical prehistory $\mathrm{ZrOCl}_{2} \times 8 \mathrm{H}_{2} \mathrm{O}, \mathrm{Zr}(\mathrm{acac})_{3}$, and $\mathrm{Zr}\left(\mathrm{OBu}^{n}\right)_{4}$. Excitation was at $262 \mathrm{~nm}$. Observation was at $614 \mathrm{~nm}$

depend significantly on the method of their preparation (Fig. 8). The isotherms presented for nanopowders obtained from acetylacetonate solutions of zirconium and europium, as well as their chlorides, clearly belong to the IV type characteristic of mesoporous materials. Capillary condensation of the adsorbent can occur in the pores of these materials, which in turn leads to the appearance of hysteresis between adsorption and desorption isotherms (Fig. 8a). The course of the capillary-condensation hysteresis loop for these nanopowders according to IUPAC classification can be attributed to the $\mathrm{H} 2$ type, which indicates the presence of bottle-shaped mesopores in it. At the same time, for $\mathrm{ZrO}_{2}-2 \mathrm{~mol} \% \mathrm{EuO}_{1.5}$ nanoparticles obtained from zirconium (IV) butoxide solution and europium acetylacetonate hydrate, the sorption isotherm is close to the I type, which is inherent mainly to microporous samples. However, the observed hysteresis between the adsorption and desorption branches makes it possible to classify them also as an IV type.

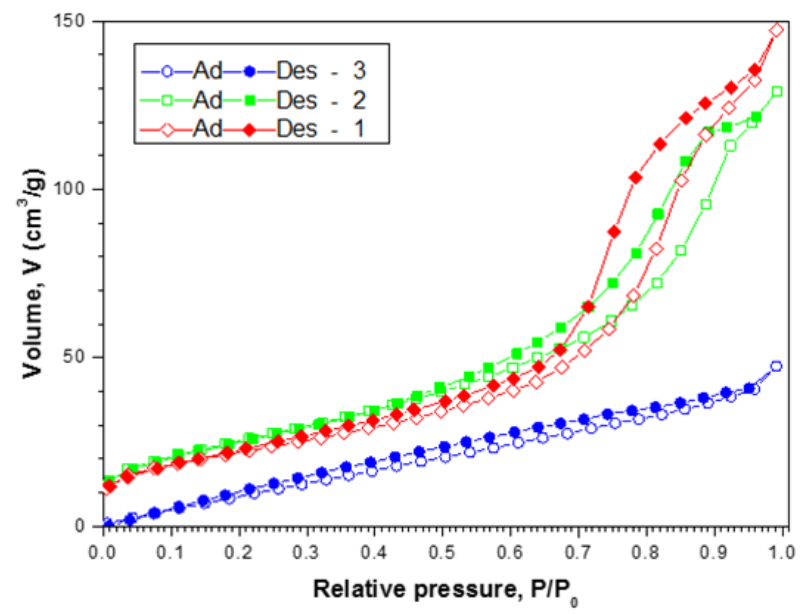

(a)

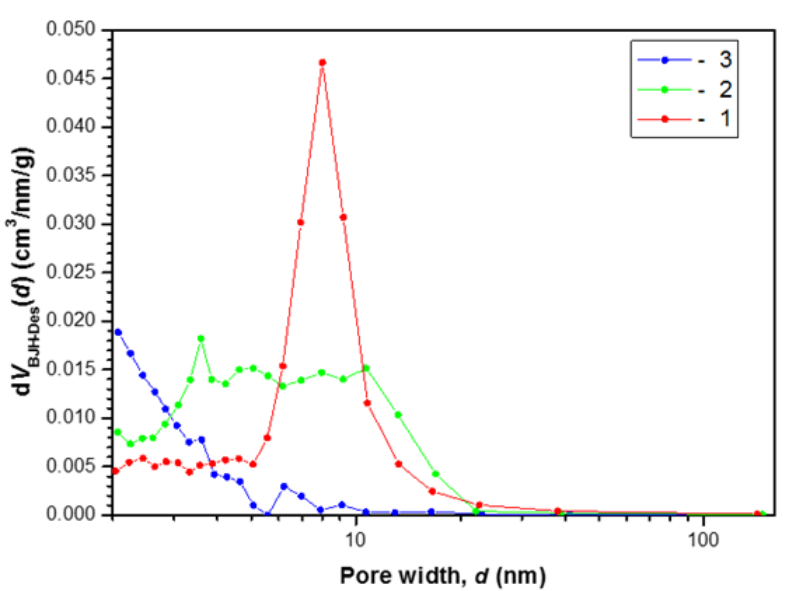

(b)

FIG. 8. Adsorption-desorption isotherms (a) and $\mathrm{BJH}$ distributions of pore size (b) $\mathrm{Zr}_{0.98} \mathrm{Eu}_{0.02} \mathrm{O}_{1.99}$ nanoparticles synthesized from $\mathrm{ZrOCl}_{2} \times 8 \mathrm{H}_{2} \mathrm{O}$ and $\mathrm{EuCl}_{3} \times 6 \mathrm{H}_{2} \mathrm{O}$ (1), $\mathrm{Zr}(\mathrm{acac})_{4}$ and $\mathrm{Eu}(\mathrm{acac})_{3} \times n \mathrm{H}_{2} \mathrm{O}(2)$, as well as $\mathrm{Zr}\left(\mathrm{OBu}^{n}\right)_{4}$ and $\mathrm{Eu}(\mathrm{acac})_{3} \times n \mathrm{H}_{2} \mathrm{O}$ (3) 
TABLE 4. The surface properties of $\mathrm{Zr}_{0.98} \mathrm{Eu}_{0.02} \mathrm{O}_{1.99}$ nanoparticles with a different chemical prehistory, measured by the method of low-temperature nitrogen adsorption and electrophoretic light scattering

\begin{tabular}{|c|c|c|c|c|}
\hline Chemical prehistory & $S_{B E T}, \mathrm{~m}^{2} / \mathrm{g}$ & $D_{\text {pore }}, \mathrm{nm}$ & $V_{\text {pore }}$, $\mathrm{cm}^{3} / \mathrm{g}$ & $\zeta$-potential, $\mathrm{mV}$ \\
\hline \hline $\mathrm{ZrOCl}_{2} \times 8 \mathrm{H}_{2} \mathrm{O} / \mathrm{EuCl}_{3} \times 6 \mathrm{H}_{2} \mathrm{O}$ & $80.2 \pm 2.4$ & 8 & 0.24 & -8.7 \\
\hline $\mathrm{Zr}(\mathrm{acac})_{4} / \mathrm{Eu}(\mathrm{acac})_{3} \times n \mathrm{H}_{2} \mathrm{O}$ & $91.6 \pm 1.8$ & - & 0.20 & -4.2 \\
\hline $\mathrm{Zr}\left(\mathrm{OBu}^{n}\right)_{4} / \mathrm{Eu}(\mathrm{acac})_{3} \times n \mathrm{H}_{2} \mathrm{O}$ & $96.6 \pm 3.9$ & - & 0.05 & 15.3 \\
\hline
\end{tabular}

*The specific volume of pores is determined by the limiting filling $\left(P / P_{0}=0.99\right)$.

The pore size distribution in $\mathrm{Zr}_{0.98} \mathrm{Eu}_{0.02} \mathrm{O}_{1.99}$ nanopowders, obtained from different precursors, was calculated for the desorption branch according to the $\mathrm{BJH}$ algorithm and is presented in Fig. 8b. The nanoparticle powder obtained from a toluene solution of $\mathrm{Zr}\left(\mathrm{OBu}^{n}\right)_{4} / \mathrm{Eu}(\mathrm{acac})_{3} \times n \mathrm{H}_{2} \mathrm{O}$ is characterized by a gradual pore size decrease in the range from 2 to $10 \mathrm{~nm}$, which confirms the presence of both micro- and mesopores in it. A wide trapezoidal distribution of mesopores is observed in sizes ranging from $c a$. 3 to $20 \mathrm{~nm}$, with a small number of micropores in the case of a sample synthesized from acetylacetonate hydrates of zirconium and europium. Moreover, only nanoparticles obtained by hydrothermal treatment of the $\mathrm{ZrO}(\mathrm{OH})_{2}-\mathrm{Eu}(\mathrm{OH})_{3}$ composition is characterized by a lognormal distribution of mesopores in the range from 5 to $20 \mathrm{~nm}$ with a maximum at $\mathrm{ca} .8 \mathrm{~nm}$.

In a series of $\mathrm{Zr}_{0.98} \mathrm{Eu}_{0.02} \mathrm{O}_{1.99}$ nanoparticles obtained from different precursors, the highest survival of fibroblast cells was observed in a suspension of phosphors with the largest specific surface area and positive values of the zeta potential (Table 4). Moreover, the degree of cell culture survival in aqueous dispersions of $\mathrm{ZrO}_{2}-2$ mol.\% $\mathrm{EuO}_{1.5}$ nanoparticles, obtained from $\mathrm{Zr}\left(\mathrm{OBu}^{n}\right)_{4} / \mathrm{Eu}(\mathrm{acac})_{3} \times n \mathrm{H}_{2} \mathrm{O}$, in the concentration range of $5-500 \mu \mathrm{g} / \mathrm{ml}$ varies quite weakly compared with other phosphors synthesized in this study (Fig. 9). Thus, the stabilization of the cubic zirconia modification by selecting of zirconium alkoxide as initial material in the synthesis allows the production of nanoparticles with a more developed surface and smallest cytotoxicity.

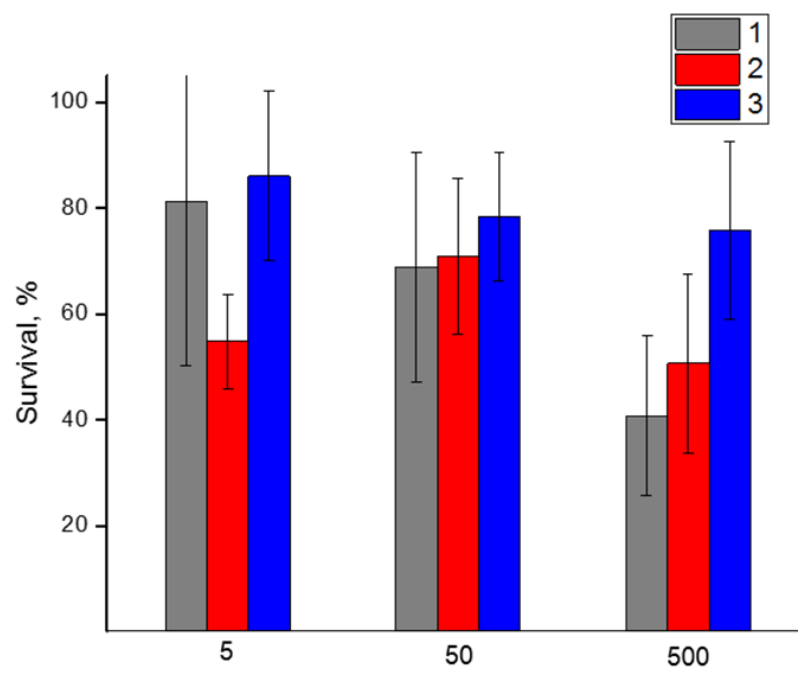

FIG. 9. MTT-test on human dermal fibroblasts in the dispersions of $\mathrm{ZrO}_{2}-2$ mol.\% $\mathrm{EuO}_{1.5}$ nanoparticles obtained from different precursors: $\mathrm{ZrOCl}_{2} \times 8 \mathrm{H}_{2} \mathrm{O} / \mathrm{EuCl}_{3} \times 6 \mathrm{H}_{2} \mathrm{O}$ (1), $\mathrm{Zr}(\mathrm{acac})_{4} / \mathrm{Eu}(\mathrm{acac})_{3} \times n \mathrm{H}_{2} \mathrm{O}(2), \mathrm{Zr}\left(\mathrm{OBu}^{n}\right)_{4} / \mathrm{Eu}(\text { acac })_{3} \times n \mathrm{H}_{2} \mathrm{O}$ (3) 


\section{Conclusion}

As a result of the performed studies it is established that at the same content of Eu (III) in a reaction mixture crystallization of three polymorphic forms is observed, as in case of $\mathrm{ZrO}(\mathrm{OH})_{2}-\mathrm{Eu}(\mathrm{OH})_{3}$ dehydration under hydrothermal conditions, and for solvothermal treatment of zirconium and europium chelating compounds. In the latter case, the content of monoclinic and cubic phases of $\mathrm{ZrO}_{2}$ is higher. It has been noted that the solvothermal treatment of zirconium butoxide and europium acetylacetonate hydrate under similar conditions leads mainly to the crystallization of nanoparticles with the structure of $\mathrm{ZrO}_{2}$ metastable phases. It was possible based on measurements of quantum yields to connect the luminescence efficiency with the presence of monoclinic phase in the series of $\mathrm{Zr}\left(\mathrm{OBu}^{n}\right)_{4} / \mathrm{Eu}(\mathrm{acac})_{3} \times n \mathrm{H}_{2} \mathrm{O} \rightarrow \mathrm{ZrOCl}_{2} \times 8 \mathrm{H}_{2} \mathrm{O} / \mathrm{EuCl}_{3} \times 6 \mathrm{H}_{2} \mathrm{O} \rightarrow \mathrm{Zr}(\mathrm{acac})_{4} / \mathrm{Eu}(\mathrm{acac})_{3} \times n \mathrm{H}_{2} \mathrm{O}$ for $\mathrm{Zr}_{0.98} \mathrm{Eu}_{0.02} \mathrm{O}_{1.99}$ nanoparticles. It has been revealed that the more $\mathrm{Zr}_{0.98} \mathrm{Eu}_{0.02} \mathrm{O}_{1.99}$ crystallites with monoclinic structure are formed in hydrothermal and solvothermal conditions of synthesis, the higher the quantum yield of $\mathrm{Eu}^{3+}$ luminescence is, and the shorter emission times are fixed. According to MTT-test, the metabolic activity of cells is preserved after three days of human fibroblast incubation in an aqueous dispersion of $\mathrm{ZrO}_{2}-2 \mathrm{~mol} \% \mathrm{EuO}_{1.5}$ nanoparticles, which indicates that they practically no cytotoxicity. Stabilization of more symmetrical $t, c-\mathrm{ZrO}_{2}$ modifications in the process of solvothermal synthesis by selecting $\mathrm{Zr}\left(\mathrm{OBu}^{n}\right)_{4}$ and $\mathrm{Eu}(\mathrm{acac})_{3} \times n \mathrm{H}_{2} \mathrm{O}$ as precursors made it possible to obtain nanoparticles with a high surface/volume ratio and a positive zeta potential value, whose dispersions showed the highest survival rate of fibroblasts cells. Thus, the selection of synthesis conditions (nature of the precursor, type of solvent, and isothermal holding time) allows for varying the phase composition of the formed $\mathrm{Zr}_{1-x} \mathrm{Eu}_{x} \mathrm{O}_{2-0.5 x}$ nanoparticles. Moreover, the combination of the most effective monoclinic modification for luminescence with the least cytotoxic cubic phase of zirconia makes it possible to obtain phosphors with the required quantum yield and extinction coefficients, which have potential for application in biophotonics and medicine.

\section{Acknowledgements}

Alexander N. Bugrov acknowledges the Russian Foundation for Basic Research (grant No. 16-33-60227) for the financial support. The experimental work was facilitated by the Engineering Center equipment of the St. Petersburg State Technological Institute (Technical University). The quantum yield and Raman spectroscopy measurements were determined at the Center for Optical and Laser Materials Research, St. Petersburg State University. TEM studies were performed using equipment of the Federal Joint Research Center "Material science and characterization in advanced technology" supported by the Ministry of Education and Science of the Russian Federation (id RFMEFI62117X0018). The authors are grateful to Kirilenko D. A. from the Ioffe Institute for the study of samples obtained in this article by TEM. The authors are also appreciative to Kryukov A. E. from Institute of Macromolecular Compounds RAS for cytotoxicity studies and Rodionov I. A. from Institute of Chemistry, St. Petersburg State University for bandgap measurements.

\section{References}

[1] Di Bartolo B., Collins J., Silvestri L. Nano-Optics: Principles enabling basic research and applications, NATO Science for Peace and Security Series B: Physics and Biophysics, Springer Netherlands, 2017, $584 \mathrm{p}$.

[2] Gai S., Li C., Yang P., Lin, J. Recent progress in rare earth micro/nanocrystals: Soft chemical synthesis, luminescent properties, and biomedical applications. Chem. Rev., 2014, 114 (4), P. 2343-2389.

[3] Luo W., Liu Y., Chen X. Lanthanide-doped semiconductor nanocrystals: electronic structures and optical properties. Science China Materials, 2015, 58 (10), P. 819-850.

[4] Chakraborty A., Debnath G.H., et al. Identifying the correct host - guest combination to sensitize trivalent lanthanide (guest) luminescence: Titanium dioxide nanoparticles as a model host system. J. Phys. Chem. C, 2016, 120 (41), P. 23870-23882.

[5] Raj A.K.V., Rao P.P., Sreena T.S., Thara T.R.A. Influence of local structure on photoluminescence properties of $\mathrm{Eu}^{3+} \mathrm{doped}^{\mathrm{CeO}} \mathrm{C}_{2}$ red phosphors through induced oxygen vacancies by contrasting rare earth substitutions. Phys. Chem. Chem. Phys., 2017, 19, P. 20110-20120.

[6] Gallino F., Di Valentin C., Pacchioni G. Band gap engineering of bulk $\mathrm{ZrO}_{2}$ by Ti doping. Phys. Chem. Chem. Phys., 2011,13 , P. 17667.

[7] Basahel S.N., Ali T.T., Mokhtar M., Narasimharao K. Influence of crystal structure of nanosized $\mathrm{ZrO}_{2}$ on photocatalytic degradation of methyl orange. Nanoscale Research Letters, 2015, 10 (1), P. 73

[8] Lovisa L.X., Andres J., et al. Photoluminescent properties of $\mathrm{ZrO}_{2}: \mathrm{Tm}^{3+}, \mathrm{Tb}^{3+}, \mathrm{Eu}^{3+}$ powders - Acombined experimental and theoretical study. Journal of Alloys and Compounds, 2017, 695, P. 3094-3103.

[9] Yamamoto O., Arachi Y., et al. Zirconia based oxide ion conductors for solid oxide fuel cells. Ionics, 1998, 4 (5-6), P. 403-408.

[10] Sinhamahapatra A., Jeon J.-P., et al. Oxygen-deficient zirconia $\left(\mathrm{ZrO}_{2-x}\right)$ : A new material for solar light absorption. Sci. Rep., 2016, 6, P. 27218.

[11] Martin L.P., Glass R.S. Hydrogen sensor based on yttria-stabilized zirconia electrolyte and tin-doped indium oxide sensing electrode. Journal of the Electrochemical Society, 2004, P. 22.

[12] Hernández S., Gionco C., et al. Insights into the sunlight-driven water oxidation by Ce and Er-doped ZrO 2 . Front. Chem., 2018 , 6, P. 368.

[13] Bugrov A.N., Rodionov I.A., et al. Photocatalytic activity and luminescent properties of Y, Eu, Tb, Sm and Er-doped $\mathrm{ZrO}_{2}$ nanoparticles obtained by hydrothermal method. Int. J. Nanotechnology, 2016, 13 (1/2/3), P. 147-157 
[14] Garnweitner G. Zirconia nanomaterials: Synthesis and biomedical application. Nanotechnologies for the Life Sciences, 2010,8 , P. $245-285$.

[15] Almjasheva O.V., Garabadzhiu A.V., et al. Biological effect of zirconium dioxide-based nanoparticles. Nanosystems: physics, chemistry and mathematics, 2017, 8 (3), P. 391-396.

[16] Ceja-Fdez A., López-Luke T., et al. Labeling of HeLa cells using $\mathrm{ZrO}_{2}: \mathrm{Yb}^{3+}{ }_{-} \mathrm{Er}^{3+}$ nanoparticles with upconversion emission. Journal of Biomedical Optics, 2015, 20 (4), P. 046006.

[17] Liu Y., Zhou S., et al. Amine-functionalized lanthanide-doped zirconia nanoparticles: Optical spectroscopy, time-resolved fluorescence resonance energy transfer biodetection, and targeted imaging. J. Am. Chem. Soc., 2012, 134, P. 15083-15090.

[18] Escribano P., Julian-Lopez B., et al. Photonic and nanobiophotonic properties of luminescent lanthanide-doped hybrid organic-inorganic materials. J. Mater. Chem., 2008, 18, P. 23-40.

[19] Dunne P.W., Munn A.S., et al. Continuous-flow hydrothermal synthesis for the production of inorganic nanomaterials. Phil. Trans. R. Soc. $A, 2015,373$, P. 20150015.

[20] Almjasheva O.V., Smirnov A.V., et al. Structural features of $\mathrm{ZrO}_{2}-\mathrm{Y}_{2} \mathrm{O}_{3}$ and $\mathrm{ZrO}_{2}-\mathrm{Gd}_{2} \mathrm{O}_{3}$ nanoparticles formed under hydrothermal conditions. Russian Journal of General Chemistry, 2014, 84 (5), P. 804-809.

[21] Moon B.K., Kwon I.M., et al. Synthesis and luminescence characteristics of Eu ${ }^{3+}$-doped $\mathrm{ZrO}_{2}$ nanoparticles. Journal of Luminescence, 2007, 122-123, P. 855-857.

[22] Almjasheva O.V., Denisova T A. Water state in nanocrystals of zirconium dioxide prepared under hydrothermal conditions and its influence on structural transformations. Russian Journal of General Chemistry, 2017, 87 (1), P. 1-7.

[23] Dudnik E.V. Modern methods for hydrothermal synthesis of $\mathrm{ZrO}_{2}$-based nanocrystalline powder. Powder Metallurgy and Metal Ceramics, 2009, 48 (3-4), P. 146-158.

[24] Bugrov A.N., Almjasheva O.V. Effect of hydrothermal synthesis conditions on the morpholgy of $\mathrm{ZrO}_{2}$ nanoparticles. Nanosystems: physics, chemistry and mathematics, 2013, 4 (6), P. 810-815.

[25] Hobbs H., Briddon S., Lester E. The synthesis and fluorescent properties of nanoparticulate $\mathrm{ZrO}_{2}$ doped with Eu using continuous hydrothermal synthesis. Green Chem., 2009, 11, P. 484-491.

[26] Tiseanu C., Cojocaru B., et al. Order and disorder effects in nano- $\mathrm{ZrO}_{2}$ investigated by micro-Raman and spectrally and temporarily resolved photoluminescence. Phys. Chem. Chem. Phys., 2012, 14, P. 12970-12981.

[27] Smits K., Olsteins D., et al. Doped zirconia phase and luminescence dependence on the nature of charge compensation. Scientific Reports, 7, P. 44453

[28] Bugrov A.N., Smyslov R.Yu., et al. Phase composition and photoluminescence correlations in nanocrystalline $\mathrm{ZrO}_{2}: \mathrm{Eu}^{3+}$ phosphors synthesized under hydrothermal conditions. Nanosystems: physics, chemistry and mathematics, 2018,9 (3), P. $378-388$.

[29] Meetei S.D., Singh S.D. Effects of crystal size, structure and quenching on the photoluminescence emission intensity, lifetime and quantum yield of ZrO:Eu nanocrystals. Journal of Luminescence, 2014, 147, P. 328-335.

[30] Bugrov A.N., Smyslov R.Yu., et al. Soluble and insoluble polymer-inorganic systems based on poly(methyl methacrylate), modified with $\mathrm{ZrO}_{2}-\mathrm{LnO}_{1.5}(\mathrm{Ln}=\mathrm{Eu}, \mathrm{Tb})$ nanoparticles: Comparison of their photoluminescence. Journal of Luminescence, 2019, 207 , P. 157-168.

[31] Melekh N.V., Frolova S.V., Aleshina L.A. X-Ray analysis of powdered celluloses obtained with the use of Lewis acids. Polymer Science, Ser. A, 2014, 56, P. 129-136.

[32] Bortolotti M., Lutterotti L., Lonardelli I. ReX: a computer program for structural analysis using powder diffraction data. J. Appl. Cryst., 2009, 42 (3), P. 538-539.

[33] Bugrov A.N., Zavialova A.Yu., et al. Luminescence of $\mathrm{Eu}^{3+}$ ions in hybrid polymer-inorganic composites based on poly(methyl methacrylate) and zirconia nanoparticles. Luminescence, 2018, P. 1-13.

[34] DeMello J.C., Wittmann H.F., Friend R.H. An improved experimental determination of external photoluminescence quantum efficiency. Advanced Materials, 1997, 9, P. 230-232.

[35] Smith D.K., Newkirk H.W. The crystal structure of baddeleyite (monoclinic $\mathrm{ZrO}_{2}$ ) and its relation to the polymorphism of $\mathrm{ZrO}_{2}$. Acta Crystallographica, 1965, 18, P. 983-991.

[36] Igawa N., Ishii Y. Crystal structure of metastable tetragonal zirconia up to 1473 K. J. Am. Ceram. Soc., 2001,84 (5), P. $1169-1171$.

[37] Martin U., Boysen H., Frey F. Neutron powder investigation of tetragonal and cubic stabilized zirconia, TZP and CSZ, at temperatures up to 1400 K. Acta Crystallographica Section B, 1993, 49 (3), P. 403-413.

[38] Hecht H.G. The interpretation of diffuse reflectance spectra. Journal of Research of the National Bureau of Standards - A. Physics and Chemistry, 1976, 80 (4), 567.

[39] Heine C., Girgsdies F., et al. The model oxidation catalyst $\alpha-\mathrm{V}_{2} \mathrm{O}_{5}$ : insights from contactless in situ microwave permittivity and conductivity measurements. Appl. Phys. A, 2013, 112 (2), P. 289-296.

[40] Garcia J.C., Scolfaro L.M.R., et al. Structural, electronic, and optical properties of $\mathrm{ZrO}_{2}$ from ab initio calculations, 2012, ArXiv:1204.2886v1 [cond-mat.mtrl-sci].

[41] Bunzli J.-C. G. On the design of highly luminescent lanthanide complexes. Coordination Chemistry Reviews, $2015,293-294$, P. $19-47$.

[42] Tamrakar R.K., Bisen D.P., Upadhyay K., Tiwari S. Synthesis and thermoluminescence behavior of $\mathrm{ZrO}_{2}: \mathrm{Eu}^{3+}$ with variable concentration

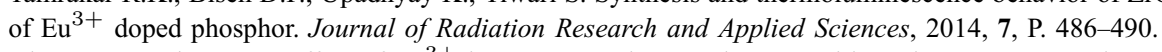

[43] Ahemen I., Dejene F.B. Effect of $\mathrm{Eu}^{3+}$ ion concentration on phase transition, site symmetry and quantum efficiency of $\mathrm{ZrO}_{2}$ nanocrystal rods. Journal of Nanoscience and Nanotechnology, 2018, 18, P. 2429-2440. 